were, however, not grounds for excluding patients whom we thought would have something to gain by relief of their aortic stenosis. If a procedure is to be offered to these patients valve replacement relieves stenosis without creating regurgitation, and its benefits will endure.

RUSSELL MILLNER TOM TREASURE

Middlesex Hospital HOWARD SWANTON

London WIN 8AA

1 Levine MJ, McKay RG. Percutaneous balloon valve dilatation BrMed f 1989;298:620-1. (11 March.)

2 Cribier A, Savin T, Saoudi N, Rocha P, Berland J, Letac B. Percutaneous transluminal valvuloplasty of acquired aortic Percutaneous transluminal valvuloplasty of acquired aortic
stenosis in elderly patients: an alternative to valve replacement? Lancet 1986; ; $63-7$.

3 Sprigings DC, Jackson GJ, Chambers JB, et al. Balloon dilatation of the aortic valve for inoperable aortic stenosis. Br Med $\mathcal{Y}$ 1988:297:1007-11.

4 Markland CG, Pugsley WG, Treasure T, Swanton RH. Is there a limit to operability in aortic stenosis? Br Heart f 1989;61:126.

\section{Hypothyroidism in polymyalgia rheumatica and giant cell arteritis}

SIR, - We were surprised that Dr P Wiseman and colleagues could find only a single case report on the association of hypothyroidism with polymyalgia rheumatica and giant cell arteritis.'

In 1978 we showed that of 250 patients with autoimmune thyroid disease, seven $(2 \cdot 8 \%)$ had polymyalgia rheumatica or giant cell arteritis. Al the cases occurred in women aged over 60 , a prevalence of $9 \cdot 3 \%$. Among our controls- 150 women aged over 50 attending a cardiac clinic - no cases were found. We concluded that the strong association between polymyalgia rheumatica-giant cell arteritis syndrome and thyroid disease had important clinical and therapeutic implications. We advised that this association should be deliberately sought by clinical inquiry, routine palpation of the temporal arteries, and, when appropriate, determination of the erythrocyte sedimentation rate in this group of vulnerable patients - namely, elderly women with autoimmune thyroid disease.

O M EDWARDS R G DENT

\section{Addenbrooke's Hospital}

Cambridge CB2 $2 Q Q$

1 Wiseman P, Stewart K, Rai GS. Hypothyroidism in polymyalgia rheumatica and giant cell arteritis. Br Med f 1989;298:647-8. (11 March.)

2 Dent RG, Edwards OM. Autoimmune thyroid disease and the polymyalgia rheumatica-giant cell arteritis syndrome. polymyalgia rheumatica-gian
Clin Endocrinol 1978;9:215-9.

\section{Popper and Lakatos's syndrome}

SIR, - I am grateful to Professor Leslie Collier' not only for setting the record straight about the work of Stephen Black and his colleagues on the inhibition of the Mantoux test by deep hypnotic suggestion ${ }^{2}$ but also for reminding me sharply that there is no excuse for failing to check the facts before rushing into print, even in an Opinion column.

The point that I was illustrating was that when the best scientists are faced with an observation that seems to falsify their prevailing theory they generally do not - as Sir Karl Popper suggests they should-abandon the theory. Instead-as Imre Lakatos argued - they often pursue investigations in such a way as to hold firm the underlying "core theory" as long as it is tenable, while modifying a "protective belt" of auxiliary theories that are more expendable.
Stephen Black had shown in a series of experiments that allergic responses could be inhibited under deep hypnotic suggestion. On the face of it, this cast doubt on the accepted, purely somatic, theories of the immune response. Hence the experiment in question, which, as Professor Collier reminds us, showed that it was not the fundamental immune response (the "core theory") which was affected by suggestion. Professor Collier has rightly blown my hyperbole sky high, but in doing so has strengthened the case in favour of Lakatos's syndrome.

JOHN GABBAY

Southampton $\mathrm{SO} 2 \mathrm{IGA}$

1 Collier L. Popper and Lakatos's syndrome. Br Med f 1989;298: 1036. (15 April.)

2 Black S, Humphrey JH, Niven JSF. Inhibition of Mantoux reaction by direct suggestion under hypnosis. Br Med $\mathcal{f}$ 1963;i:1649-52.

\section{Cardiac catheterisation as an outpatient procedure}

SIR,-Dr K G Oldroyd and colleagues show a dangerously casual attitude to health economics; their calculation that the transfer from inpatient to day patient care may save $£ 35000$ is almost certainly wrong.' It was made by multiplying an average figure for the cost of bed usage by the number of cases performed. To calculate the saving accurately marginal rather than average costs must be considered; this requires a more careful assessment.

Furthermore, Dr Oldroyd and colleagues described the objective as a cost-benefit assessment; to study whether a procedure should be done by one method or another, however, requires a cost effective study. Their consideration of both costs and benefits is extremely limited. Benefits such as whether patients spent less time off work or costs such as those which might fall on general practitioners as the result of the change might have been considered.

Finally, beds are rarely spared unless they are actually removed from the hospital; other patients will be treated in the beds that the cardiologists stop using. Hospital financial managers reading Dr Oldroyd and colleagues' paper might assume that they had found a nice little saving. They would be disappointed.

Manchester M14 5NP

PAUL KINNERSLEY

1 Oldroyd KG, Phadke KV, Phillips R, Carson PHM, Clarke M, Davis JAS. Cardiac catheterisation by the Judkins technique as an outpatient procedure. Br Med f 1989;298:875-6. (1 April.)

SIR,-Dr K G Oldroyd and colleagues' figures for major complications of cardiac catheterisation performed as a day patient procedure in a group of low risk patients ${ }^{1}$ are important because of the current interest in the possibility of devolving catheterisation facilities from regional centres to the district hospitals.

Dr Oldroyd and colleagues found a mortality of $\mathbf{0 . 2 \%}$ for left ventriculography and coronary arteriography in patients considered to be suitable for investigation as day patients. The mortality from other series, when all cases are included, is $0 \cdot 1-0 \cdot 2 \% .^{2+4}$ The risk is, however, closely related to functional class and to the severity of coronary disease. The conventionally accepted figure in low risk patients (functional classes I and II) is $0.02 \%$. We believe, however, that the potential mortality is much higher than this, particularly if the facilities for emergency coronary artery bypass are not available.

Of the 11216 procedures performed in the cardiac catheter laboratory at this hospital between 1983 and 1988, 5781 patients with suspected coronary artery disease and no other cardiac diagnosis had left ventriculography and coronary arteriography. Fourteen patients (eight men and six women, mean age 59), whose investigation had been considered routine (eight were day patients), had profound circulatory collapse during the procedure (coronary dissection (seven), coronary occlusion (five), and global ischaemia (two)). Twelve patients went immediately to the operating theatre, one died in the catheter laboratory before transfer to the theatre, and one went to the theatre two hours after catheterisation. After surgery three patients died in hospital and the 10 who survived were alive at follow up from one to 24 (mean 10) months after discharge.

In our experience even in patients considered to be at low risk the incidence of a major complication requiring emergency coronary surgery was at least $0 \cdot 24 \%$. Survival in these patients was $77 \%$. These findings and the access to cardiac surgery should be considered when planning facilities for cardiac catheterisation.

J T STEWART

D E WARD C W PUMPHREY DAVID REDWOOD

Cardiac Department,

Knightsbridge Wing,

St George's Hospital,

Seorge's Hospital

Wessex Cardiothoracic Centre,

Southampton

I Oldroyd KG, Phadke KV, Phillips PHM, Clarke M, Davis JAS Cardiac catheterisation by the (Judkins technique as an outpatient procedure. Br Med f 1989;298:875-6. (1 April.)

2 Davis K, Kennedy JW, Kemp HG, Judkins MP, Gosselin AJ, Killip T. Complications of coronary arteriography from the collaborative study of coronary artery surgery (CASS). Circulation 1979;59:1105-11.

3 Kennedy JW, Baxley WA, Bunnell IL, et al. Mortality related to cardiac catheterization and angiography. Cathet Cardiozasc Diagn 1982;8:323-40.

4 Kennedy JW. Complications associated with cardiac catheterization and angiography. Cathet Cardiovasc Diagn 1982;8:5-11.

\section{Self referral to an accident and emergency department}

SIR,-Drs Christopher S Jones and Alastair McGowan report an increasing tendency for self referral to their accident and emergency department for a second opinion.'

They identified less than $1 \%$ of new attendances, however, as falling within this category, which strongly contrasts with observations in other districts. For example, $27 \%$ of new attenders to a paediatric accident and emergency department ${ }^{2}$ and $16 \%$ of those at a district department ${ }^{3}$ were self referred after a general practitioner consultation. During a pilot study for a study that is currently under way into self referral to the accident and emergency department at this hospital 18 out of 83 self referrals $(22 \%)$ with problems suitable for general practitioner care (about half of all new attenders) had previously consulted their general practitioner, a similar proportion to that reported at The London Hospital."

We do not think that Drs Jones and McGowan are justified in making any inferences from their data unless they provide evidence of validation as we suspect that they have seriously underidentified the study population. The large proportion of patients subsequently admitted or referred to outpatient clinics in their study suggests that in the case of seriously ill patients who self referred there was a bias towards recording previous general practitioner consultation. Moreover, patients may have denied seeking a second opinion to avoid compromising their eligibility for accident and emergency treatment.

In our study we too are finding that rates of self referral for another opinion vary among general 